\title{
The first reported cases of elephant endotheliotropic herpesvirus infectious haemorrhagic disease in Malaysia: case report
}

\author{
Mei-Ho Lee ${ }^{1,3^{*}+} \oplus$, Senthilvel K. S. S. Nathan ${ }^{2,5 \dagger}$, Laura Benedict ${ }^{5}$, Pakeeyaraj Nagalingam ${ }^{5}$, Erin Latimer ${ }^{4}$, \\ Tom Hughes ${ }^{1,3}$, Diana Ramirez ${ }^{5 \wedge}$ and Jum Rafiah Abd Sukor ${ }^{2}$
}

\begin{abstract}
Background: Elephant endotheliotropic herpesvirus haemorrhagic disease (EEHV HD) is the leading cause of death in captive Asian elephant calves in Asia, North America, and Europe with a mortality rate of $~ 65 \%$ in calves that are under human care. Although EEHV HD was first found in elephant camps, more recently it was identified in wild populations which poses a greater threat to the elephant population. Deaths due to EEHV HD have been seen in wild elephants, but the in-situ prevalence and mortality rate is unknown. We report the first EEHV HD cases in Malaysia from 3 wild born endangered Bornean elephant calves from Sabah with known typical clinical signs.
\end{abstract}

Case presentation: The first calf died within $24 \mathrm{~h}$ of the onset of clinical signs; the second calf died within $12 \mathrm{~h}$ of the onset of clinical signs. The third calf succumbed within $72 \mathrm{~h}$. Necropsies revealed that all 3 calves had similar presentations of EEHV HD but in the third calf with less severity. We conducted conventional polymerase chain reaction (CPCR) assays and found EEHV DNA at all 7 loci in the 3 calves; it was identified as EEHV1A, the virus type that has been found in most other reported cases.

Conclusion: Typical EEHV HD clinical signs and the molecular confirmation of EEHV by CPCR and sequencing point to EEHV as the cause of death. Further genetic investigation of the strain is in progress.

Keywords: Bornean elephant, Elephant endotheliotropic herpesvirus, Sabah, Malaysia

\section{Background}

Elephant endotheliotropic herpesvirus (EEHV) was the first and so far, only described herpesvirus causing critical disease in elephants with visible morphological changes [1] and resulted in an $85 \%$ fatality rate in infected individuals [2, 3]. Following a novel EEHV report [2], more than 100 similar cases have been identified across the globe. Captive born juvenile Asian elephants (Elephas maximus) were affected in the majority of the confirmed

\footnotetext{
*Correspondence: mei-ho@conservationmedicine.org

${ }^{\dagger}$ Mei-Ho Lee and Senthilvel K. S. S. Nathan have Joint first authors

${ }^{1}$ Conservation Medicine, 47000 Sungai Buloh, Selangor, Malaysia Diana Ramirez: Deceased 31st October 2018

Full list of author information is available at the end of the article
}

cases $[4,5]$. Over the past 20 years, this disease has had a mortality rate of $65 \%$ in young Asian elephants between 3 months to 15 years of age in Europe and North America in human care [3]. Furthermore, EEHV haemorrhagic cases are increasingly reported in the endemic wild and captive populations in Asia [3, 6-9].

Most EEHV cases linked with systemic endotheliolytic disease affecting Asian elephants belong to the EEHV1 group (EEHV1A and EEHV1B), although there has been several cases of morbidity and mortality due to EEHV4 and EEHV5 in Asian elephants [10-14]. Historically there had been two deaths due to EEHV2 in African elephants (Loxodonta africana) and a death due to EEHV6, [4, 15] as well as a survivor of EEHV3B [16] and EEHV6 [13]. Since 2019, there have been three deaths, five survivors original author(s) and the source, provide a link to the Creative Commons licence, and indicate if changes were made. The images or other third party material in this article are included in the article's Creative Commons licence, unless indicated otherwise in a credit line to the material. If material is not included in the article's Creative Commons licence and your intended use is not permitted by statutory regulation or exceeds the permitted use, you will need to obtain permission directly from the copyright holder. To view a copy of this licence, visit http://creativecommons.org/licenses/by/4.0/. The Creative Commons Public Domain Dedication waiver (http://creativeco mmons.org/publicdomain/zero/1.0/) applies to the data made available in this article, unless otherwise stated in a credit line to the data. 
of EEHV HD, and five cases of barely clinical/subclinical EEHV, all due to either EEHV3A or EEHV3B, as well as a death from EEHV2 and what seems to have been a wellcontrolled viraemia from EEHV6 [17, Latimer E, personal communication]. Though the transmission mechanisms of EEHV have not been fully understood, viral DNA is found in trunk secretions and other bodily fluids and is believed to be involved in transmission [18].

EEHV-infected elephants display an acute onset of lethargy, generalised oedema of head and limbs, oral ulceration, cyanosis of the tongue, tachycardia, and death after a period of 1-7 days. Lymphopenia and thrombocytopenia are commonly seen in blood evaluations. Increasingly, there are reports of elephants surviving EEHV HD with treatment including antivirals, fluids, platelets, and immunostimulants, among other therapies [4, 17, 19-23]. Pericardial effusion, intestinal haemorrhage, and mucosal ulcerations are common necropsy findings. Target tissues for EEHV include heart, tongue, liver, and large intestine. Histological examinations usually reveal microhaemorrhages, oedema and inflammation in these organs. Lesions can be accompanied by intranuclear herpesvirus inclusions in capillary endothelial cells [1].

There is no prior report published of EEHV infection in Malaysia or from the Bornean elephant-a subspecies of Asian elephant on the island of Borneo, mainly in Sabah, a state in East Malaysia. Bornean elephants, Elephas maximus borneensis, are one of the four distinct subspecies of the Asian elephants. They are classified as endangered according to the International Union for Conservation of Nature (IUCN) Red list of threatened species due to habitat loss. More recently, the species is also threatened from illegal hunting, poisoning and attacks by those trying to protect crops. Sabah has an ex-situ population of 24 elephants in human care at the Sepilok Orangutan Rehabilitation Centre, (Sandakan, SORC), Borneo Elephant Sanctuary (Kinabatangan) and Lok Kawi Wildlife Park (Kota Kinabalu). The state's wild population is estimated at 2000 individuals [24].

There are two hypotheses regarding the origins of these elephants-they were introduced to Borneo either from Sulu [25] or Sumatera and Peninsular Malaysia or were indigenous to Borneo but derived from a Sundaic stock [26]. Genetic studies of mitochondrial DNA divergence supports the latter hypothesis [26, 27]. In the wild, they can be found at the northern and north-eastern parts of Borneo in the state of Sabah in Malaysia and the upper Sembakung River in Kalimantan, Indonesia [28]. With the many rampant threats including EEHV HD, low population numbers and the uniqueness of the species in terms of its habitat range and genetic makeup, the conservation and the health of this species is tremendously important to ensure the survival of this iconic species in the wild and in human care.

\section{Case presentation}

The first occurrence of EEHV infection at SORC occurred in a 24-month-old E. m. borneensis calf (Table 1). Symptomatic treatment (prednisolone $1 \mathrm{mg} / \mathrm{kg}$, papase, oxytetracycline $20 \mathrm{mg} / \mathrm{kg}$, intravenous fluid therapy) was administered. The calf died within $24 \mathrm{~h}$ of the onset of clinical signs. Over $1 \mathrm{~L}$ of serosanguinous epicardial fluid

Table 1 Details of the E. m. borneensis tested and their PCR results

\begin{tabular}{|c|c|c|c|c|c|c|c|}
\hline Animal & $\begin{array}{l}\text { Date and place of } \\
\text { rescue }\end{array}$ & Sex & $\begin{array}{l}\text { Age and weight } \\
\text { during the } \\
\text { outbreak }\end{array}$ & $\begin{array}{l}\text { Date of initial } \\
\text { disease signs }\end{array}$ & $\begin{array}{l}\text { 1st collection } \\
\text { (11 May 2016) }\end{array}$ & $\begin{array}{l}\text { 2nd collection } \\
\text { (25 May 2016) }\end{array}$ & $\begin{array}{l}\text { PCR results with } \\
\text { sequencing } \\
\text { confirmation }\end{array}$ \\
\hline Jimbo (First case) & $\begin{array}{l}\text { February 2014; Beluran, } \\
\text { Sabah }\end{array}$ & Male & 24 months; 362 kg & 9th May 2016 & Not collected & Not collected & $+^{*}$ \\
\hline Vinodh (Second case) & $\begin{array}{l}\text { November 2014; Telu- } \\
\text { pid, Sabah }\end{array}$ & Male & 24 months; 442 kg & 17th May 2016 & WB, S & WB, S & + \\
\hline Tuntan (Third case) & $\begin{array}{l}\text { February 2014; Sukau, } \\
\text { Sabah }\end{array}$ & Male & 36 months; 478 kg & 20th May 2016 & WB, S & $S$ & + \\
\hline Danum & $\begin{array}{l}\text { December 2015; Lahad } \\
\text { Datu, Sabah }\end{array}$ & Male & 24 months; 289 kg & $\mathrm{N} / \mathrm{A}$ & WB, S & $\mathrm{S}$ & - \\
\hline Budak & $\begin{array}{l}\text { February 2016, Kina- } \\
\text { batangan, Sabah }\end{array}$ & Male & 5 months; $97.5 \mathrm{~kg}$ & $\mathrm{~N} / \mathrm{A}$ & WB, S & $\mathrm{S}$ & - \\
\hline Tunku & $\begin{array}{l}\text { February 2016, Kina- } \\
\text { batangan, Sabah }\end{array}$ & Male & 5 months; $118 \mathrm{~kg}$ & $\mathrm{~N} / \mathrm{A}$ & WB, S & $S$ & - \\
\hline Adun & $\begin{array}{l}\text { April 2015; Telupid, } \\
\text { Sabah }\end{array}$ & Male & 12 months; 247 kg & $\mathrm{N} / \mathrm{A}$ & WB, S & $\mathrm{S}$ & + \\
\hline Dumpas & $\begin{array}{l}\text { August 2015; Tawau, } \\
\text { Sabah }\end{array}$ & Male & 21 months; 372 kg & $\mathrm{N} / \mathrm{A}$ & WB, S & $\mathrm{S}$ & - \\
\hline
\end{tabular}

WB, whole blood; S, serum; +, EEHV detected; -, EEHV not detected; N/A, not applicable

*PCR confirmation from organs, not from WB using subsequent PCR protocols only 
(Fig. 1D) was retrieved from the pericardial sac. The calf had facial swelling (Fig. 1A). Over 6-12 h the swelling increased, and discolouration of the tongue apex was observed (Fig. 1B). The necropsy revealed prominent facial and truncal oedema with cyanotic swollen tongue. Generalised subcutaneous petechiation (Fig. 1C) with moderate subcutaneous oedema was observed. Severe haemorrhaging was evident in the heart extending from the epicardium through the myocardium and papillary musculatures (Fig. 1E). Generalised haemorrhage and oedema along the gastrointestinal tract including the mesentery was observed (Fig. 1F), and the liver was enlarged with mild petechiation.

Following the first calf's death, all other elephants at the SORC were administered acyclovir $19 \mathrm{mg} / \mathrm{kg}$, oxytetracycline $20 \mathrm{mg} / \mathrm{kg}$, vitamin $C$ and virgin coconut oil supplements. The second EEHV case occurred 8 days later in another 24-month-old calf (Table 1). Intravenous fluid therapy was administered immediately, but the calf died less than $12 \mathrm{~h}$ later. The third death occurred 3 days later in a 36-month-old calf (Table 1). Treatment as described above was given. The calf regained appetite for milk and solid food the next day following intensive fluid therapy (rectal and intravenous). Nevertheless, on the next morning, the calf stopped eating and died several hours later.

The necropsy of the second dead calf revealed similar findings to the first one. The necropsy of the third calf showed similar findings to the first two calves but with less severity. Dullness, inappetence and lethargy were observed in all cases. While tongue cyanosis and swelling, and facial and trunk oedema were only observed in the first two calves. Vesicles and oral ulceration were not observed in all three calves.

Organ samples were collected from all three dead calves for Escherichia coli culture and histopathological examination. Blood samples from the last two dead calves and from five apparently healthy elephants from the SORC (Table 1) were stored and tested at the Wildlife Health, Genetic and Forensic Laboratory (WHGFL), Kota Kinabalu, Sabah, a certified biosafety level 2 laboratory, at the request of the Sabah Wildlife Department and with Sabah Biodiversity Centre approval (SaBC License Number: JKM/MBS.1000-2/2JLD.5). DNA was extracted from these samples using the QIAamp Blood and Tissue Mini Kit (Qiagen, Hilden, Germany). For immediate diagnosis, conventional PCR amplifications

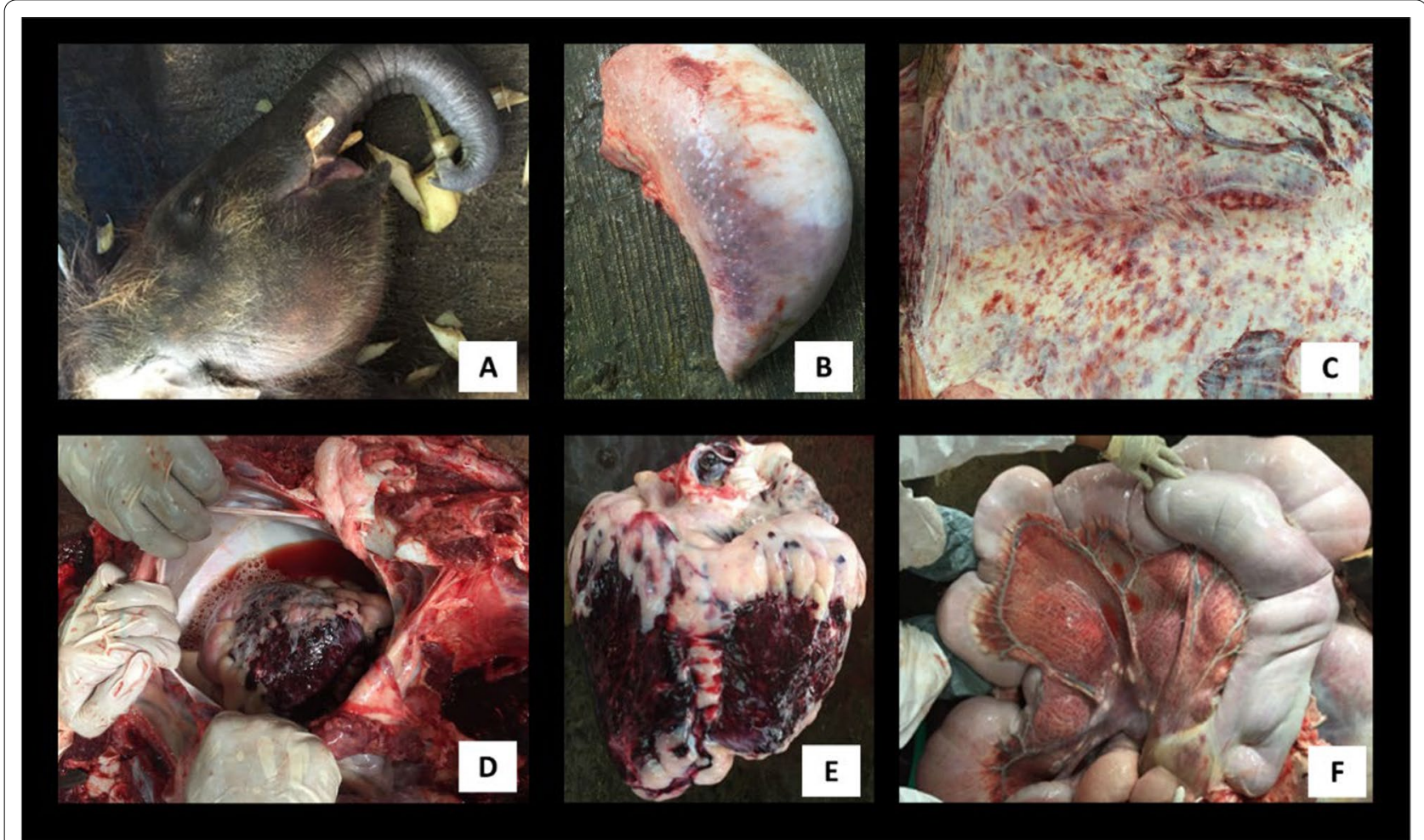

Fig. 1 Necropsy findings of EEHV. A Marked facial and trunk oedema in the first case with tongue cyanosis. B Tongue discolouration due to internal haemorrhaging in the second case (also observed in the first case). C Diffuse subcutaneous petechiation observed in all 3 cases. D Pericardial effusion from the first case but present in all three cases. $\mathbf{E}$ Heart of the first case, severe cardiac haemorrhage. $\mathbf{F}$ Generalised haemorrhage of gastrointestinal tract observed in all 3 cases 
were conducted on the extracted DNA for herpesviruses using consensus $[29,30]$ and EEHV PCRs [4, 13] (Table 2). For further genetic investigations on the variabilities on these loci, all blood and organ samples were rescreened at WHGFL with PCRs on conserved gene loci-U60(TERex3), U71(gM), and U77(HEL) and on hypervariable gene loci-U48.5(TK), U48(gH-TK), U51(vGPCR1), and E54(vOX2-1) [Hayward G, unpublished data, 31] (Table 3). Since the serum and whole blood from the first dead calf were unavailable, initial consensus and EEHV PCRs were not performed for this animal. Instead, the organ samples were used for the subsequent EEHV PCRs.

Correct sized PCR products on electrophoresis agarose were excised and purified using the QIAquick Gel Extraction Kit (Qiagen, Hilden, Germany). Purified products were sequenced using their corresponding specific primers. The nucleotide sequences were analysed with the Geneious 10.1.3 software (Auckland, New Zealand) and compared to sequences in GenBank for homology analysis using the Basic Local Alignment Search Tool (BLAST; National Center for Biotechnology Information). Cleaned sequences from the initial EEHV PCR were aligned with
17 published EEHV DNA polymerase sequences using the Geneious Prime 2021.1.1 software (Auckland, New Zealand) Geneious Alignment (Alignment type: Global alignment with free end gaps; Cost matrix: Identity, Table 4). Aligned sequences were used to build a phylogenetic tree using the Geneious Prime 2021.1.1 software (Auckland, New Zealand) Geneious Tree Builder, with the Jukes-Cantor genetic distance model and 1000 bootstrap replicates (Fig. 2).

Histopathological examination showed that inclusion bodies were insignificant in the organs of the three calves, but the histopathological lesions were suggestive of enteritis in the first calf and viral infection in the second and third. Using the consensus terminase and polymerase herpesvirus, the polymerase specific EEHV 3/4 and the EEHV terminase PCR assays, herpesvirus was not detected in all tested samples. Of the seven individuals from the SORC screened using the polymerase pan EEHV PCR assays, three individuals (second and third dead calves and one of the five healthy animals) were sequence-confirmed for EEHV, with 91-93\% identical sequences to EEHV $1 \mathrm{~A}$ and $1 \mathrm{~B}$ (North American isolates) and elephantid herpesvirus

Table 2 Initial diagnosis PCR protocols and primers used

\begin{tabular}{|c|c|c|c|}
\hline Target gene & Primer sequences $\left(5^{\prime}-3^{\prime}\right)$ & Product length (bp) & References \\
\hline Terminase & $\begin{array}{l}\text { Round 1: } \\
\text { TS-TERM_707s: TTGTGGACGAGRSIMAYTTYAT } \\
\text { TS-TERM_707as: ACAGCCACGCCNGTICCIGAIGC } \\
\text { Round 2: } \\
\text { TS-TERM_708s: GCAAGATCATNTTYRTITCITC } \\
\text { TS-TERM_708as: TGTTGGTCGTRWAIGCIGGRT }\end{array}$ & $\begin{array}{l}\text { Round 1: } 519 \\
\text { Round 2: } 419\end{array}$ & [29] \\
\hline Polymerase & $\begin{array}{l}\text { Round 1: } \\
\text { DFA: GAYTTYGCNAGYYTNTAYCC } \\
\text { KG: GTCTTGCTCACCAGNTCNACNCCYTT } \\
\text { ILK:TCCTGGACAAGCAGCARNYSGCNMTNAA } \\
\text { KG1: GTCTTGCTCACCAGNTCNACNCCYTT } \\
\text { Round 2: } \\
\text { TGV:TGTAACTCGGTGTAYGGNTTYACNGGNGT } \\
\text { IYG: CACAGAGTCCGTRTCNCCRTADAT }\end{array}$ & $\begin{array}{l}\text { Round 1: } \\
\text { DFA/KGI: 750 } \\
\text { ILK/KGI: } 480 \\
\text { Round 2: } 215-315\end{array}$ & [30] \\
\hline $\begin{array}{l}\text { EEHV DNA Polymerase- } \\
\text { Specific EEHV } 3 / 4\end{array}$ & $\begin{array}{l}\text { 6719: CGTTGAAGGTGTCGCAGAT } \\
\text { 7400: CAGCATCATCCAGGCCTACAAC } \\
\text { 6720: ATCCTGGCGCAGCTGCTGAC } \\
\text { 6721: CTCACCTGCAACGCCGTCTA }\end{array}$ & $\begin{array}{l}\text { Round 1: } \\
\text { 6719/7400: } 390 \\
\text { Round 2: } \\
\text { 6719/6720: } 270 \\
\text { Round 3: } \\
\text { 6719/6721: } 150\end{array}$ & [13] \\
\hline $\begin{array}{l}\text { EEHV DNA Polymerase- } \\
\text { PAN EEHV and specific EEHV } 6\end{array}$ & $\begin{array}{l}\text { 6710: ACAAACACGCTGTCRGTRTCYCCRTA } \\
\text { 6711: GTATTTGATTTYGCNAGYYTGTAYCC } \\
\text { 6712: TGYAAYGCCGTNTAYGGATTYACCGG } \\
\text { 7584: CATCGATTTTGAACTTCTCATGGTC }\end{array}$ & $\begin{array}{l}\text { Round 1: } \\
\text { 6710/6711: } 500 \\
\text { Round 2A: 6710/6712: } 250 \\
\text { Round 2B: 6711/7584: } 500 \\
\text { Round 3A: } \\
\text { 6712/7584: } 250\end{array}$ & [13] \\
\hline EEHV DNA Terminase & $\begin{array}{l}\text { B1 LGH2425: ACAGCCACGCCNGTNCCNGANGC } \\
\text { A2 LGH2428: TTGTGGACGAGRSNMAYTTYAT } \\
\text { A3 LGH2426: GCAAGATCATNTTYRTNTCNTC } \\
\text { B2 LGH2427: TGTTGGTCGTRWANGCNGGRTC } \\
\text { A3SEQ: CCCCATCTGAGCAAGATCAT } \\
\text { B2SEQ: GGCTGACAAATGTTGGTCGT }\end{array}$ & $\begin{array}{l}\text { Round 1: } \\
\text { B1/A2: } 575 \\
\text { Round 2: } \\
\text { A3/B2: } 415 \text { A3SEQ/B2SEQ: } 360\end{array}$ & [4] \\
\hline
\end{tabular}


Table 3 Subsequent PCR protocols and primers used

\begin{tabular}{|c|c|c|c|}
\hline Genes/loci & Primer sequences $\left(5^{\prime}-3^{\prime}\right)$ & Product length (bp) & Accession number \\
\hline U60(TERex3) & $\begin{array}{l}\text { LGH6640: AAATGTTCTATTCCGTATAC } \\
\text { LGH6672: CATGTTGTGCAGGCACTCTTC } \\
\text { LGH6671: GTTTGTAGTAAATGCCGGATC } \\
\text { LGH6672: CATGTTGTGCAGGCACTCTTC }\end{array}$ & $\begin{array}{l}\text { Round 1: } \\
\text { 6640/6672: } 850 \\
\text { Round 2: } \\
\text { 6671/6672: } 780\end{array}$ & JX011056-62 \\
\hline U71(gM) & $\begin{array}{l}\text { LGH6749: CTATGGGATCCGAACTTTC } \\
\text { LGH6752: CTACATGCCCATGCAGATAGG } \\
\text { LGH6750: CTTTCTAAGGGGGTTTGTGC } \\
\text { LGH6752: CTACATGCCCATGCAGATAGG }\end{array}$ & $\begin{array}{l}\text { Round 1: } \\
\text { 6749/6752: } 730 \\
\text { Round 2: } \\
\text { 6750/6752: } 710\end{array}$ & JX011063-71 \\
\hline U77(HEL) & $\begin{array}{l}\text { LGH6743: GCAAGGTRGAACGTATCGTCG } \\
\text { LGH6742: CACAGMGCGTTGTAGAACC } \\
\text { LGH6743: GCAAGGTRGAACGTATCGTCG } \\
\text { LGH6742: CACAGMGCGTTGTAGAACC }\end{array}$ & $\begin{array}{l}\text { Round 1: } \\
\text { 6732/6742: } 680 \\
\text { Round 2: } \\
\text { 6743/6742: } 680\end{array}$ & JX01 1072-79 \\
\hline U48.5(TK) & $\begin{array}{l}\text { LGH6764: GCACGRTACCACGTACTC } \\
\text { LGH7968: GCGGCAACGAAGTTCACAGGCATYATGG } \\
\text { LGH7968: GCGGCAACGAAGTTCACAGGCATYATGG } \\
\text { LGH7970: TGCMGCYTGAAGGCTGTTATATACT }\end{array}$ & $\begin{array}{l}\text { Round 1: } \\
\text { 6764/7968: } 750 \\
\text { Round 2: } \\
\text { 7968/7970: } 640\end{array}$ & MN864103.1 \\
\hline U48(gH-TK) & $\begin{array}{l}\text { LGH7981: CTRCATTKMCCAAAGTATGGAAGTA } \\
\text { LGH7985: GGTAGGTTCACCTACATGGAACTTC } \\
\text { LGH7982: CRTYTATATCATCAAARACYTCACA } \\
\text { LGH7985: GGTAGGTTCACCTACATGGAACTTC }\end{array}$ & $\begin{array}{l}\text { Round 1: } \\
\text { 7981/7985: } 1080 \\
\text { Round 2: } \\
\text { 7982/7985: } 1040\end{array}$ & JX01 1039-46 \\
\hline U51 (vGPCR1) & $\begin{array}{l}\text { LGH7506: GATTGTGAACGCTGTATGCT } \\
\text { LGH4963B: GACTTTCTTCGTAGCCCTCGTCTT } \\
\text { LGH7506: GATTGTGAACGCTGTATGCT } \\
\text { LGH5200A: CGTGATACGCTTCAAAACATACA }\end{array}$ & $\begin{array}{l}\text { Round 1: } \\
\text { 7506/4963B: } 910 \\
\text { Round 2: } \\
\text { 7506/5200A: } 750\end{array}$ & JX01 1047-55 \\
\hline E54(VOX2-1) & $\begin{array}{l}\text { LGH8471: ATGCTTCAGAGAAAGTACAGGTAC } \\
\text { LGH8472: GTGTTGCCGCCACGATGCTTCTACG } \\
\text { LGH8471: ATGCTTCAGAGAAAGTACAGGTAC } \\
\text { LGH8506: CTA CGC CAC TTG TAA CAG AAT ATC ACG }\end{array}$ & $\begin{array}{l}\text { Round 1: } \\
\text { 8471/8472: } 910 \\
\text { Round 2: } \\
\text { 8471/8506: } 890\end{array}$ & MF464882-899 \\
\hline
\end{tabular}

Table 4 Cleaned sequences of the initial PCR of pan EEHV DNA polymerase, Round 2A using 6710/6712 [13]

\begin{tabular}{|c|c|}
\hline $\begin{array}{l}\text { Accession number } \\
\text { and sample name }\end{array}$ & Sequence (length in bp) \\
\hline OK635292 Adun S & $\begin{array}{l}\text { TTGAATCCTATTACTGTCTACCGGGCAGTCAACTAGTTCGGGAGCTATTTGCGTTAAGAACGTCCAATCGTTAAATCTGTCGCAAATATATTG } \\
\text { GTTGGTAACGGCCAGCAGTTGTCTGCCCTGCGCCGTGACCGATTCAGCTATGGCCAGACAGGGAAACATCCCTTTCGACACACCGGT } \\
\text { GAATCCATACACGGCATTGCAAA (203) }\end{array}$ \\
\hline OK635293 Vinodh S & $\begin{array}{l}\text { TCGATTTTGATCTATTACTGTCTACCGGGCAGTCAACTAGTTCGGGAGCTATTTGCGTTAAGAACGTCCAATCGTTAAATCTGTCGCAAATAT } \\
\text { ATTGTTTGGTAACGGCCAGCAGTTGTCTGCCCTGCGCCGTGACCGATTCAGCTATGGCCAGACAGGGAAACATCCCTTTCGACACACCGG } \\
\text { TGAATCCATACACGGCATTGCAAA (207) }\end{array}$ \\
\hline OK635294 Tuntan S2 & $\begin{array}{l}\text { CATCGATTTTGATCTATTACTGTCTACCGGGCAGTCAACTAGTTCGGGAGCTATTTGCGTTAAGAACGTCCAATCGTTAAATCTGTCGCAAAT } \\
\text { ATATTGTTTGGTAACGGCCAGCAGTTGTCTGCCCTGCGCCGTGACCGATTCAGCTATGGCCAGACAGGGAAACATCCCTTTCGACACACC } \\
\text { GGTGAATCCATACACGGCATTGCAA (208) }\end{array}$ \\
\hline OK635295 Vinodh WB2 & $\begin{array}{l}\text { TCGATTTTGATCTATTACTGTCTACCGGGCAGTCAACTAGTTCGGGAGCTATTTGCGTTAAGAACGTCCAATCGTTAAATCTGTCGCAAATAT } \\
\text { ATTGTTTGGTAACGGCCAGCAGTTGTCTGCCCTGCGCCGTGACCGATTCAGCTATGGCCAGACAGGGAAACATCCCTTTCGACACACCGG } \\
\text { TGAATCCATACACGGCATTGCAAG (207) }\end{array}$ \\
\hline
\end{tabular}

WB2 Whole blood from second collection, $\mathrm{S}$ serum, $\mathrm{S} 2$ serum from second collection

1 DNA polymerase. Phylogenetic analysis showed that there was $100 \%$ sequence agreement within the three calves with the initial EEHV PCR detection and they were more related to EEHV 1A from Lao (Accession no. KJ400033.1) than the other sequences used for the comparison. The EEHV detection for the first dead calf was confirmed with sequences from the followup PCRs. The detailed analysis of the results from the follow-up genetic investigations will be presented in a subsequent manuscript.

\section{Discussion and conclusions}

These are the first reported cases anywhere of EEHV HD in Bornean elephants (Elephas maximus borneensis). However, the lack of previous reports in Malaysia does not necessarily indicate a low EEHV HD morbidity. 


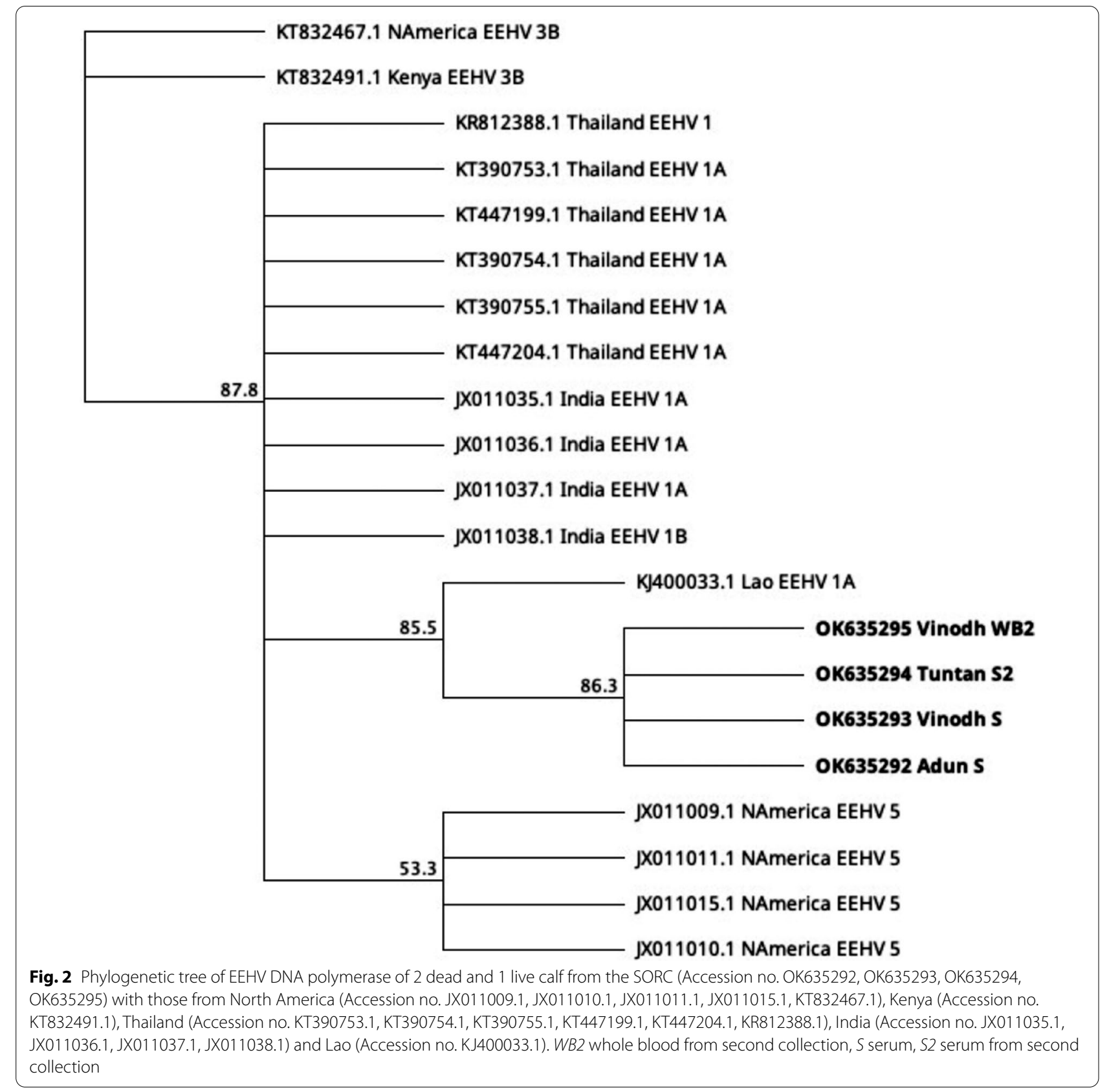

Initially, EEHV was hypothesised to be a novel virus for Asian elephants spread via exposure to African elephants in captivity [2]. However, in 2012, Asian elephants were shown to be the host with detection in wild Indian elephants [3] as well as other subsequent detections of EEHV in wild and camp elephants in Asia [9, 31]. Our cases support the latter, as the affected animals had no prior contact with African elephants.
Shedding by herd members could be the source of infection in vulnerable calves; the source of the SORC outbreak is not known. The EEHV may have been shed by the two youngest calves, aged less than 12 months old rescued four months prior to the outbreak, that may have still been protected by maternal antibodies. The calves that died were older than 24 months; none of the younger calves exhibited any clinical signs, although 
EEHV was detected in one of them. This is consistent with other fatal cases in individuals above 24 months old $[4,10]$, with maternal antibodies generally waning by 24 months old, explaining the higher fatality in slightly older calves [32].

Most fatal EEHV HD cases are of juvenile Asian elephants, ranging from 12 to 84 months old and usually dying within $24 \mathrm{~h}$ of the first detectable clinical signs [2, 10]. The course of the disease in the first two calves was peracute, both dying in less than $24 \mathrm{~h}$ from the onset of clinical signs, the third calf died after $72 \mathrm{~h}$. Viraemia can occur several days prior to the onset of clinical signs and by this time severe vascular lesions would have developed [10]. Nevertheless, keepers should still be trained to identify the signs of the disease. Immediate administration of antiviral drugs might prevent further vascular damage, but its efficacy remains unclear and needs more investigation [23, 33]. A symptomatic treatment regime, including intensive fluid therapy, anti-inflammatories, parenteral antibiotics, and vitamins, remains crucial to reduce or stop the effects of initial vascular damages [33]. The efficacy of lauric acid found in the virgin coconut oil given to the elephants for its supposedly antiviral properties [34] in the treatment of EEHV HD is inconclusive because we were not able to distinguish between the effects from the drug treatments and from the supplements. At the time of the outbreak, there was limited information available on successful treatments, new treatment guidelines published subsequently [19-23] provide useful guidance for future outbreaks.

Since this was the first time we found EEHV in our elephants, it is important to determine the prevalence, patterns of shedding and the duration of the disease. In addition, early detection by PCR is vital for preclinical viraemia detection; routine screening serves as an early warning system to better prepare elephant centres for managing imminent EEHV outbreaks. PCR monitoring after an outbreak event is also crucial. These approaches can help us to understand EEHV HD to reduce morbidity and mortality in wild and captive elephants that are already endangered through habitat loss and increasing conflict with humans.

\begin{abstract}
Abbreviations
EEHV HD: Elephant endotheliotropic herpesvirus haemorrhagic disease; CPCR: Conventional polymerase chain reaction; IUCN: International Union for Conservation of Nature; SORC: Sepilok Orangutan Rehabilitation Centre, Sandakan, Sabah; WHGFL: Wildlife Health, Genetic and Forensic Laboratory, Kota Kinabalu, Sabah; SaBC: Sabah Biodiversity Center; BLAST: Basic local alignment search tool.
\end{abstract}

\section{Acknowledgements}

Our deepest gratitude to Dr Diana Ramirez for her vital contribution to this work and wildlife conservation in Sabah. The authors thank the Sabah Wildlife
Rescue Unit Rangers in assisting with managing the outbreak at the SORC as well as assisting the veterinarians with treatments, critical care and necropsy of these elephants. The authors also thank the Sabah Biodiversity Centre for approving this research. The authors thank Dr Gary Hayward on advising on the gene selection for sequencing and Fernandes Opook of Conservation Medicine for reviewing the phylogenetic tree model used.

\section{Authors' contributions}

$\mathrm{MHL}$ advised on the testing, processed the samples, performed PCR assays, analysed and interpreted sequences and was a major contributor in preparing the manuscript. SKSSN supervised the necropsies, identified the disease from the signs, recommended treatment and contributed to writing the manuscript. LB and PN performed on-site clinical management on the sick elephants, necropsies, collected the samples and contributed to writing the manuscript. EL performed some of the PCR assays, analysed and interpreted sequences and was a major contributor in preparing the manuscript. DR arranged the logistics of samples to the lab and EL's travel to and around Sabah and helped managed the outbreak. TH advised on sample collection and testing, supported herpesviruses testing using consensus PCR and first round of specific EEHV testing, arranged approval for lab testing and was a major contributor in preparing the manuscript. JRAS oversaw the operations of the SORC and WHGFL and contributed to writing the manuscript. All authors read and approved the final manuscript.

\section{Funding}

The consensus herpesvirus PCRs were made possible in part by the generous support of the American people through the United States Agency for International Development (USAID) Emerging Pandemic Threats PREDICT Project (cooperative agreement number GHN-AOO-09-00010-00). The contents are the responsibility of the authors and do not necessarily reflect the views of USAID or the United States Government. The United States of America Embassy, Kuala Lumpur funded Erin Latimer's travel to Sabah to provide training on the gene loci PCRs.

\section{Availability of data and materials}

The datasets used and/or analysed during the current study are available from the corresponding author on reasonable request.

\section{Declarations}

Ethics approval and consent to participate

Not applicable.

\section{Consent for publication}

Not applicable.

\section{Competing interests}

The authors declare that they have no competing interests.

\section{Author details}

${ }^{1}$ Conservation Medicine, 47000 Sungai Buloh, Selangor, Malaysia. ${ }^{2}$ Sabah Wildlife Department, 88100 Kota Kinabalu, Sabah, Malaysia. ${ }^{3}$ EcoHealth Alliance, New York, NY 10018, USA. ${ }^{4}$ National Elephant Herpesvirus Laboratory, Wildlife Health Sciences Department, Smithsonian's National Zoo, Washington, DC 20008, USA. ${ }^{5}$ Wildlife Rescue Unit, Sabah Wildlife Department, 88100 Kota Kinabalu, Sabah, Malaysia.

Received: 5 August 2021 Accepted: 5 November 2021

Published online: 24 November 2021

\section{References}

1. Richman LK, Montali RJ, Cambre RC, Schmitt D, Hardy D, Hildbrandt T, et al. Clinical and pathological findings of a newly recognized disease of elephants caused by endotheliotropic herpesviruses. J Wildl Dis. 2000;36(1):1-12. https://doi.org/10.7589/0090-3558-36.1.1.

2. Richman LK, Montali RJ, Garber RL, Kennedy MA, Lehnhardt J, Hildebrandt T, Schmitt D, Hardy D, Alcendor DJ, Hayward GS. Novel 
endotheliotropic herpesviruses fatal for Asian and African elephants. Science. 1999;283:1171-6.

3. Zachariah A, Zong JC, Long SY, Latimer EM, Heaggans SY, Richman LK, et al. Fatal herpesvirus hemorrhagic disease in wild and orphan Asian elephants in southern India. J Wildl Dis. 2013;49:381-93.

4. Garner MM, Helmick K, Ochsenreiter J, Richman LK, Latimer E, Wise AG, Maes RK, Klupel M, Nordhausen RW, Zong JC, et al. Clinico-pathologic features of fatal disease attributed to new variants of endotheliotropic herpesviruses in two Asian elephants (Elephas maximus). Vet Pathol. 2009;46:97-104.

5. Long SY, Latimer EM, Hayward GS. Review of elephant endotheliotropic herpesviruses and acute hemorrhagic disease. ILAR J. 2016;56(3):283-96. https://doi.org/10.1093/ilar/ilv041.

6. Reid CE, Hildebrandt TB, Marx N, Hunt M, Thy N, Reynes JM, et al. Endotheliotropic elephant hervpes virus (EEHV) infection. The first PCRconfirmed fatal case in Asia. Vet Q. 2006;28:61-4.

7. Bouchard B, Xaymountry B, Thongtip N, Lertwatcharasarakul P, Wajjwalku W. First reported case of elephant endotheliotropic herpes virus infection in Laos. J Zoo Wildl Med. 2014;45:704-7.

8. Sripiboon S, Jackson B, Ditcham W, Holyoake C, Robertson I, Thitaram $C$, et al. Molecular characterisation and genetic variation of elephant endotheliotropic herpesvirus infection in captive young Asian elephants in Thailand. Infect Genet Evol. 2016;44:487-94.

9. Oo Z, Aung Y, Aung T, San N, Tun Z, Hayward GS, et al. Elephant endotheliotropic herpesvirus hemorrhagic disease in Asian elephant calves in logging camps, Myanmar. Emerg Infect Dis. 2020;26(1):63-9.

10. Sripiboon S, Tankaew P, Lungka G, Thitaram C. The occurrence of elephant endotheliotropic herpesvirus in captive Asian elephants (Elephas maximus): first case of EEHV4 in Asia. J Zoo Wildl Med. 2013;44(1):100-4.

11. Fuery A, Browning GR, Tan J, Long S, Hayward GS, Cox SK, et al. Clinical infection of captive Asian elephants (Elephas maximus) with elephant endotheliotropic herpesvirus 4. J Zoo Wildl Med. 2016;47(1):311-8.

12. Denk D, Redrobe S, Latimer E, Hayward GS, Cracknel J, Classens A, et al. Fatal elephant endotheliotropic herpesvirus type 5 infection in a captive Asian elephant. Vet Rec. 2012. https://doi.org/10.1136/vr.e6833.

13. Latimer E, Zong JC, Heaggans SY, Richman LK, Hayward GS. Detection and evaluation of novel herpesviruses in routine and pathological samples from Asian and African elephants: identification of two new probosciviruses (EEHV5 and EEHV6) and two new gammaherpesviruses (EGHV3B and EGHV5). Vet Microbiol. 2011;147:28-41.

14. Atkins L, Zong J-C, Tan J, Mejia A, Heaggans SY, Nofs SA, et al. Elephant endotheliotropic herpersvirus 5 , a newly recognized elephant herpesvirus associated with clinical and subclinical infections in captive Asian elephants (Elephas maximus). J Zoo Wildl Med. 2013;44(1):136-43.

15. Kongmakee P, Suttiyaporn S, Changpetch W, et al. Elephant Endotheliotropic herpesvirus type 6 infection in a captive African elephant (Loxodonta africana) in Thailand. In Proceedings of the EEHV Workshop, 2015, Houston p41.

16. Bronson E, McClure M, Sohl J, Wiedner E, Cos S, Latimer EM, et al. Epidemiologic evaluation of elephant endotheliotropic herpesvirus $3 \mathrm{~b}$ infection in an African elephant (Loxodonta africana). J Zoo Wildl Med. 2017:48(2):335-43.

17. Fayette MA, Brenner EE, Garner MM, Bowman MR, Latimer E, Proudfoot JS. Acute hemorrhagic disease due to elephant endotheliotropic herpesvirus $3 \mathrm{~A}$ infection in five African elephants (Loxodonta africana) at one north American zoological institution. J Zoo Wildl Med. 2021;52(1):35765. https://doi.org/10.1638/2020-0126.

18. Stanton JJ, Zong JC, Latimer E, Tan J, Herron A, Hayward GS, et al. Detection of pathogenic elephant endotheliotropic herpesvirus in routine trunk washes from healthy adult Asian elephants (Elephas maximus) by use of a real-time quantitative polymerase chain reaction assay. Am J Vet Res. 2010;71(8):925-33.

19. Sripiboon S, Angkawanish T, Boonprasert K, Sombutputorn P, Langkaphin W, Ditchman W, et al. Successful treatment of a clinical elephant endotheliotropic herpes virus infection: the dynamics of viral load, genotype analysis and treatment with acyclovir. J Zoo and Wildl Med. 2017:48(4):1254-9.

20. Howard LL, Schaftenaar W. Elephant endotheliotropic herpesvirus. In: Miller ER, Lamberski N, Calle PP, editors. Fowler's zoo and wild animal medicine: current therapy. St. Louis: Elsevier; 2019. p. 672-9.

21. Wissink-Argilaga N, Dastjerdi A, Molenaar FM. Using in-house hematology to direct decision-making in the successful treatment and monitoring of a clinical and subsequently subclinical case of elephant endotheliotropic herpesvirus 1b. J Zoo Wildl Med. 2019;50(2):498-502.

22. Drake GJ, Haycock J, Dastjerdi A, Davies H, Lopez FJ. Use of immunostimulants in the successful treatment of a clinical EEHV1A infection in an Asian elephant (Elephas maximus). Vet Rec Case Rep. 2020;8:e001158.

23. Khammesri S, Mathura Y, Boonprasert K, Ampasavate C, Hongwiset $D$, Brown JL, et al. Case report: successful treatment of elephant endotheliotropic herpesvirus infection in an Asian elephant (Elephas maximus) calf by oral acyclovir medication. Wildl Sci J Vet Med Sci. 2020. https://doi.org/ 10.1292/jvms.20-0375.

24. Alfred R, Ahmad AH, Payne J, William C, Ambu L. Density and population estimation of the Bornean elephants (Elephas maximus borneensis) in Sabah. J Biol Sci. 2010;10(2):92-102.

25. Cranbrook E, Payne J, Leh CMU. Origin of the elephants Elephas maximus of Borneo. Sarawak Mus J. 2007;63(84):1-25.

26. Fernando P, Vidya TNC, Payne J, Stuewe M, Davison G, Alfred RJ, et al. DNA analysis indicates that Asian elephants are native to Borneo and are therefore a high priority for conservation. PLoS Biol. 2003;1(1):110-5.

27. Sharma R, Goossens B, Heller R, Rasteiro R, Othman N, Bruford MW, Chikhi L. Genetic analyses favour an ancient and natural origin of elephants on Borneo. Sci Rep. 2018;8:880-91.

28. Sukumar R. The Asian elephant: ecology and management. 2nd ed. Cambridge: Cambridge University Press; 1993. p. 272.

29. Chmielewicz B, Goltz M, Ehlers B. Detection and multigenic characterization of a novel gammaherpesvirus in goats. Virus Res. 2001;75:87-94.

30. Van DeVanter DR, Warrener P, Bennett L, Schultz ER, Coulter S, Garber RL, Rose TM. Detection and analysis of diverse herpesviral species by consensus primer PCR. J Clin Microbiol. 1996;34:1666-71.

31. Zachariah A, Sajesh PK, Santhosh S, Bathrachalam C, Megha M, Pandiyan $J$, et al. Extended genotypic evaluation and comparison of twenty-two cases of lethal EEHV1 hemorrhagic disease in wild and captive Asian elephants in India. PLoS ONE. 2018;13:e0202438.

32. Fuery A, Pursell T, Tan J, Peng RS, Burbelo PD, Hayward GS, et al. Lethal hemorrhagic disease and clinical illness associated with elephant endotheliotropic herpesvirus 1 are caused by primary infection: implications for the detection of diagnostic proteins. J Virol. 2020;94:1-14.

33. Dastjerdi A, Seilern-Moy K, Darpel K, Steinbach F, Molenaar F. Surviving and fatal elephant endotheliotropic herpesvirus-1A infections in juvenile Asian elephants-lessons learned and recommendations on antiherpesviral therapy. BMC Vet Res. 2016;12:178-89.

34. DebMandal M, Mandal S. Coconut (Cocos nucifera L:: Arecaceae): in health promotion and disease prevention. Asian Pac J Trop Med. 2011;4(3):2417. https://doi.org/10.1016/S1995-7645(11)60078-3.

\section{Publisher's Note}

Springer Nature remains neutral with regard to jurisdictional claims in published maps and institutional affiliations. 